\title{
Carbon recovery following selective logging in tropical rainforests in Kalimantan, Indonesia
}

\author{
Tunggul Butarbutar ${ }^{1,2^{*}}$ D, Soeyitno Soedirman ${ }^{3}$, Prem Raj Neupane ${ }^{2,4,5}$ and Michael Köhl ${ }^{2,4}$
}

\begin{abstract}
Background: The knowledge gap regarding post-logging carbon recovery by increased growth is becoming more crucial to understand the significant contribution of forest to climate change mitigation. We assessed the ability of tropical forests in Indonesia to recover carbon following conventional logging. We evaluated carbon re-growth of 10,415 trees in permanent sample plots (PSPs) in East Kalimantan. Four different post-harvesting silvicultural treatments including liberation, refining, thinning, and control were applied in the PSPs. We estimated the carbon recovery period using three different scenarios of total carbon losses due to logging. In the first scenario, we used an existing factor of logging damage and increased it for assuming the range of carbon losses due to different logging practices.

Results: Under the existing conventional logging practice, the concession annually emits $51.18 \mathrm{tC} \cdot \mathrm{ha}^{-1}$, of which $16.8 \%$ are extracted from the forest as raw timber, $38 \%$ are logging losses, and $45.2 \%$ are emissions due to infrastructure development for logging operation. Increasing the logging damage factor two and three times led to an increase in carbon emission to 70.76 and $90.34 \mathrm{tC} \cdot \mathrm{ha}^{-1}$, respectively. The recovery time of the aboveground carbon is 26 years in Scenario 1, 36 years in Scenario 2, and 46 years in Scenario 3. We found no significant effect of the silvicultural treatment type on carbon recovery, but significant effect of the sites was observed.

Conclusions: We found that the time taken to restore the carbon to the level found in undisturbed forests is considerably longer than the current intervention cycles. The time needed to recover biomass and carbon-stock noticeably depends on the intensity of logging interventions, demonstrating the benefits of using improved harvesting e.g., reduced impact logging to reduce emissions. The study found that site variability has a significant effect on the carbon recovery time. Different silvicultural treatments, on the other hand, have no effect on the recovery time. The study suggests that it is not appropriate to establish an intervention cycle based on arbitrary choice; the time between interventions must be based on logging losses and site specific growth potential to ensure sustainable management of forests.
\end{abstract}

Keywords: Timber growth, Carbon recovery, Silvicultural treatment, Logging cycle, Above-ground biomass

\section{Background}

Forests play a significant role in the global carbon cycle due to their dual ability to act as a sink and a source of atmospheric carbon. From 1990 to 2007, forests sequestered $2.4 \pm 0.4$ gigatons of carbon (Gt C) annually (Pan et al.

\footnotetext{
*Correspondence: tunggul.butarbutar@giz.de

${ }^{1}$ GIZ Forest and Climate Change Program, Manggala Wanabakti Bd. Block VII

FI. 6, Jl. Gatot Subroto, Jakarta 10270, Indonesia

2University of Hamburg, World Forestry, Leuschnerstr. 91, D-21031 Hamburg,

Germany

Full list of author information is available at the end of the article
}

2011). Globally, forests store an estimated $471 \pm 93$ Gt C (West et al. 2014), of which more than half (247 Gt C) is stored in the tropical forests of Latin America (49\%), subSaharan Africa (25\%), and Southeast Asia (26\%) (Saatchi et al. 2011). While Pan et al. (2011) suggested that forests function as a carbon sink, Baccini et al. (2017) cautioned that the carbon balance of tropical ecosystems remains uncertain, and that the world's tropical forests are a net source of carbon.

Human-induced disturbances in tropical forests contribute $8 \%-15 \%$ to global greenhouse gas (GHG) emissions 
(Houghton et al. 2015), with gross tropical deforestation emission of $2.9 \pm 0.5 \mathrm{Gt} \mathrm{C} \cdot$ year ${ }^{-1}$ and compensation by regrowth of $1.6 \pm 0.5 \mathrm{Gt} \mathrm{C}$.year ${ }^{-1}$. However, the role of forest degradation by disturbances is also considered to be significant. Emissions by forest degradation, though varying from region to region, is dominated by emissions from timber harvesting and wood fuel (Köhl et al. 2015). Pearson et al. (2017) estimated total annual emissions of $2.1 \mathrm{Gt} \mathrm{C}$ of carbon dioxide $\left(\mathrm{CO}_{2}\right)$ from forest degradation, of which $53 \%$ came from timber harvest, 30\% from wood fuel harvest, and $17 \%$ from forest fires. With the continuous expansion of selective logging (Blanc et al. 2009), the carbon emission from degradation will be more significant in the dynamic carbon of forests. In 2010, around 403 million hectares (ha) of tropical forests were managed under selective logging, and around 183 million ha were managed with a management plan (Blaser et al. 2011).

While the emissions of forest management and respective carbon accounting systems have often been discussed, the ability of forests to recover biomass and carbon after logging interventions has not received much attention. Carbon fluxes from tropical deforestation and regrowth are subject to high uncertainties (DeFries et al. 2002; Sierra et al. 2012). Pan et al. (2011) estimated the re-growing of tropical forests to be about $1.65 \pm 0.71 \mathrm{Gt} C \cdot \mathrm{year}^{-1}$. Several studies showed an increase in the growth of carbon in logged compared to non-logged forests (Chapman and Chapman 1997; Pélissier et al. 1998; Bischoff et al. 2005; Berry et al. 2010; Mazzei et al. 2010; Hawthorne et al. 2012; GourletFleury et al. 2013). The reasons for this increase in growth vary. The volume of timber extracted and the level of disturbance or the intensity of logging have an impact on the rate of recovery in such a way that growth has slowed down with increased magnitude of disturbances (Chapman and Chapman 1997; Pena-Claros et al. 2008; Villegas et al. 2009; Bonnell et al. 2011; Sist et al. 2014; Vidal et al. 2016). Post-silvicultural treatment, including the integration of sustainable harvesting practices such as the implementation of reduce impact logging (RIL), is reported to show a positive impact on C-recovery (de Graaf et al. 1999; Priyadi et al. 2005; Pena-Claros et al. 2008; Villegas et al. 2009; GourletFleury et al. 2013).

Information about the ability of tropical forests to regrow after logging interventions is crucial to understand the contribution of tropical forest management practices to the global carbon budget and its consideration under Reducing Emissions from Deforestation and Forest Degradation in developing countries (REDD+) mechanism. Considerable uncertainty remains about the rate of biomass recovery in secondary forests and the influence of prior interventions on recent recovery rates (Poorter et al. 2016). Forests are widely recognized as a source of renewable resources, and the use of wood is considered carbon-neutral. However, this assumption only applies if the amount of carbon removed by timber harvesting from the forest $\mathrm{C}$-pool is compensated by timber growth processes. Hence, the decisive questions are how a forest grows after interventions and how much time is needed at given growth to compensate for carbon losses of the remaining stand. We are referring to the change in carbon due to timber growth which includes diameter growth of the survivor trees, ingrowth and mortality.

This study contributes to the forest carbon recovery literature by conducting an analysis of post logging carbon recovery in the context of selective/conventional logging followed by four different treatments: liberation, refining, thinning, and control (no treatment). More specifically, the paper: (i) assesses the magnitude of carbon emissions in the existing selective logging practice, (ii) examines the rate of carbon recovery after the selective/ conventional logging, (iii) explores whether the existing logging cycle provide sufficient time for carbon recovery, and (iv) evaluates the impact of different treatments on the post logging carbon recovery.

\section{Methods and materials \\ Study area and sites}

The study was conducted in a logging concession holder, i.e., $\mathrm{PT}^{1}$ Gunung Gajah Abadi (GGA) in East Kalimantan Province, Indonesia. The GGA is geographically located at $1^{\circ} 20^{\prime}-1^{\circ} 35^{\prime}$ North latitude and $116^{\circ} 4^{\prime}-117^{\circ} 2^{\prime}$ East longitude (Fig. 1). Based on the Köppen classification (Köppen 1884), the forest type in the GGA is classified as fully humid equatorial rain forest. Based on the data from 1971 to 1997, the mean annual rainfall in the study area is $1928 \mathrm{~mm}$ with dry season of less than a month ( 0.5 to 0.9 month) in a year. Figure 2 presents a climate diagram showing the mean monthly temperature and precipitation in the study area. The soil types of the study area are alluvial soil, latosol soil and podzolic soil.

The GGA is covered by mixed dipterocarp lowland forest which is characterized by the domination of trees in the Dipterocarpaceae. The dipterocarp trees are usually late successional and somewhat shade tolerant hardwood species. For the management of this forest, low intensity logging that opens small canopy gaps is a potentially sustainable approach (Ruslandi and Putz 2017). Over the past decades, the GGA has been selectively harvesting the fots management conducted in Indonesia (Budiaman and Pradata 2014). The cutting cycle is presently at 35 years. In the system, selective logging is followed by the post-logging treatments in the residual stands. The treatments may include liberation thinning, refining, enrichment planting etc.

${ }^{1} \mathrm{PT}$ is stand for Perseroan Terbatas (a term that represents a limited liability company in Indonesia). 


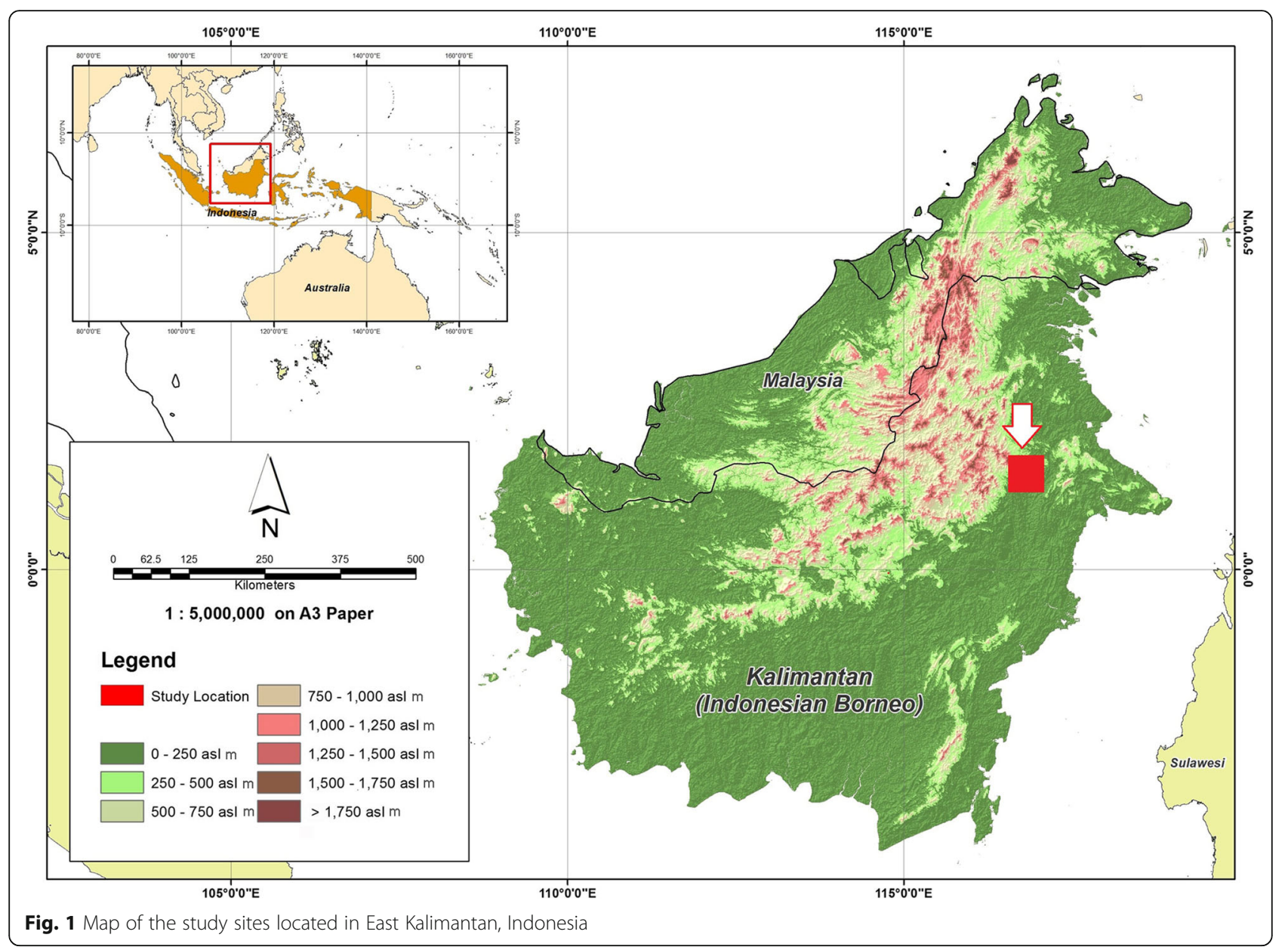

\section{Permanent sample plots, plot design and silvicultural treatments}

Under the TPTI system, permanent sample plots (PSPs) are established and distributed in the logging area to monitor logged-over forests. Ministerial Guidelines (Keputusan Menteri) No. 237/Kpts-II/1995 (Anonim 1995) mandates the forest concessions to establish a series of PSPs in the logging areas. Since 1995, the GGA has implemented a range of silvicultural treatments and monitored their impacts on the productivity by establishing a number of PSPs in its logging areas.

This study focuses on four PSPs established in four different sites in the logging area of the GGA. Each PSP consists of six sub-plots with the same plot size of 200 $\mathrm{m} \times 200 \mathrm{~m}$. Three sub-plots are located in the North and three in the South of each PSP. Within each sub-plot, the tree attributes are recorded in a $100 \mathrm{~m} \times 100 \mathrm{~m}$ measurement area located in the center of the sub-plot. The response design allows a big buffer area surrounding the measurement area within each sub-plot (Fig. 3).

The three sub-plots in the North of the PSP received three different silvicultural treatments: (i) liberation (perapihan), involves a very light cleaning of the area as to remove shrubs and liana, (ii) refinement (pembebasan), which is meant to remove all shrubs and lianas and non-commercial young trees (saplings) with a diameter at breast height $(\mathrm{DBH})(d)$ less than or equal to $5 \mathrm{~cm}$, and (iii) thinning (penjarangan), which involves the selective removal of non-commercial trees $(d>20 \mathrm{~cm})$ that compete with neighboring commercial trees. In the South of the PSP, three control sub-plots are paired with each of the sub-plots in the North. Figure 3 presents the layout of the PSP and sub-plots.

\section{Assessment of the permanent sample plots}

The Ministerial Guidelines postulates that the PSPs should be established and assessed one year after logging after being subjected to a silvicultural treatment. However, this did not happen in the study area in practice. For three sites, the first PSP assessment is postponed for several years. For example, in site 1, the PSP was assessed in 1995 one year after harvesting (1994) and assessed six times between 1996 and 2007. In site 2, logging took place in 1985, but the PSP was assessed in 


\section{Miau Baru Station (86 m)}

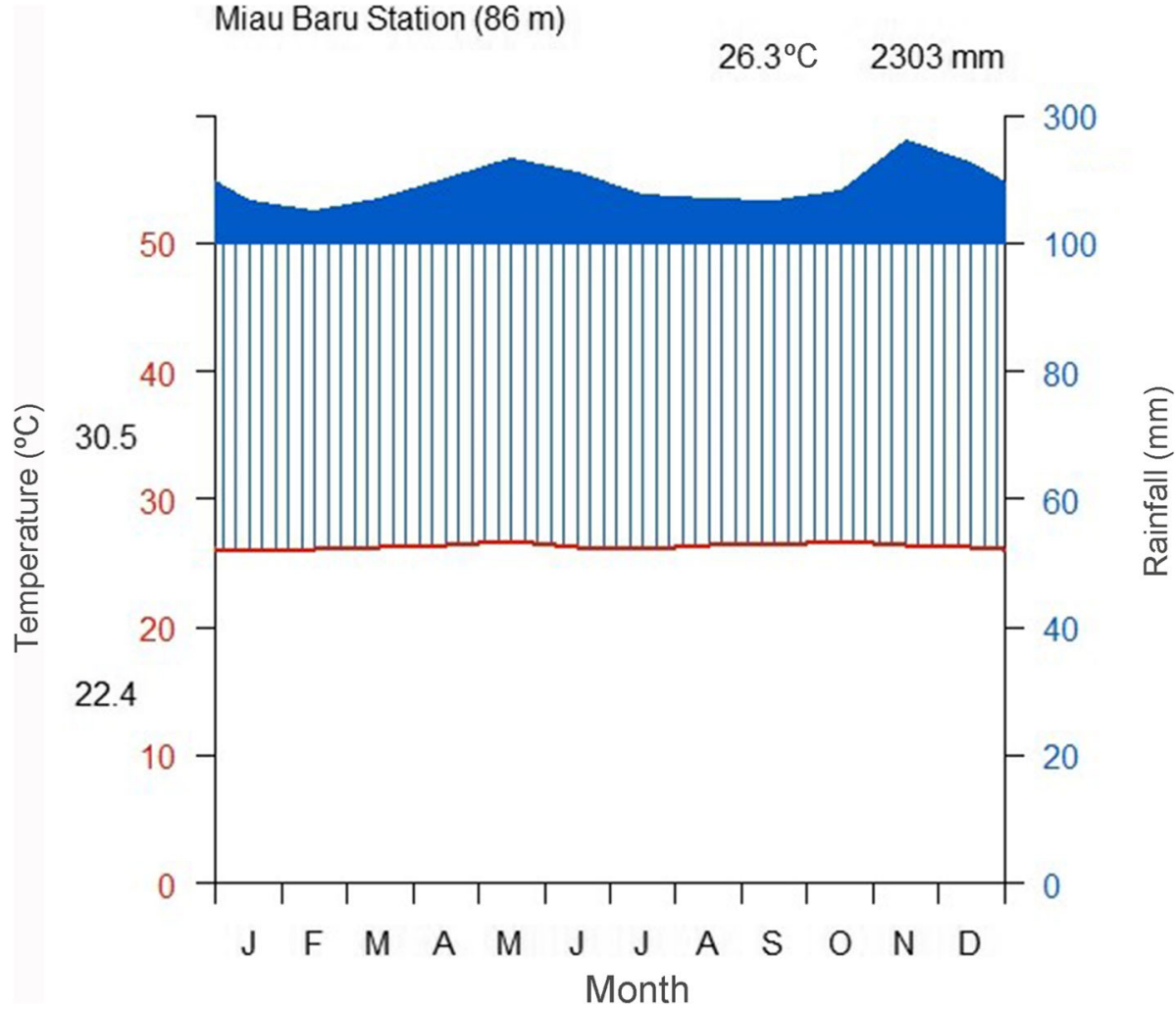

Fig. 2 A climate diagram showing annual temperature and rainfall of the study site in East Kalimantan, Indonesia. Annual temperature ranges from 22.4 to $30.5^{\circ} \mathrm{C}$ with the average of $26.3^{\circ} \mathrm{C}$, and annual rainfall ranges from 150 to $261 \mathrm{~mm} \cdot \mathrm{month}{ }^{-1}$ with total $2303 \mathrm{~mm} \cdot y e a r^{-1}$

1999 for the first time after 11 years of logging. Table 1 presents the years of PSP assessments for the four different sites.

\section{Data collection}

In the measurement area $(100 \mathrm{~m} \times 100 \mathrm{~m})$ within the sub-plot, all trees $>10 \mathrm{~cm}$ diameter $(d)$ were tagged, identified to species, and monitored for diameter increments. The tree positions were not recorded. Recruits were treated in similar ways once they reached the 10 $\mathrm{cm}$ diameter threshold.

We received the entire data sets for the four sites. The total set includes 10,415 trees (Site 1: 3,068, Site 2: 3, 396, Site 3: 1,714 and Site 4: 2,237 trees). We were able

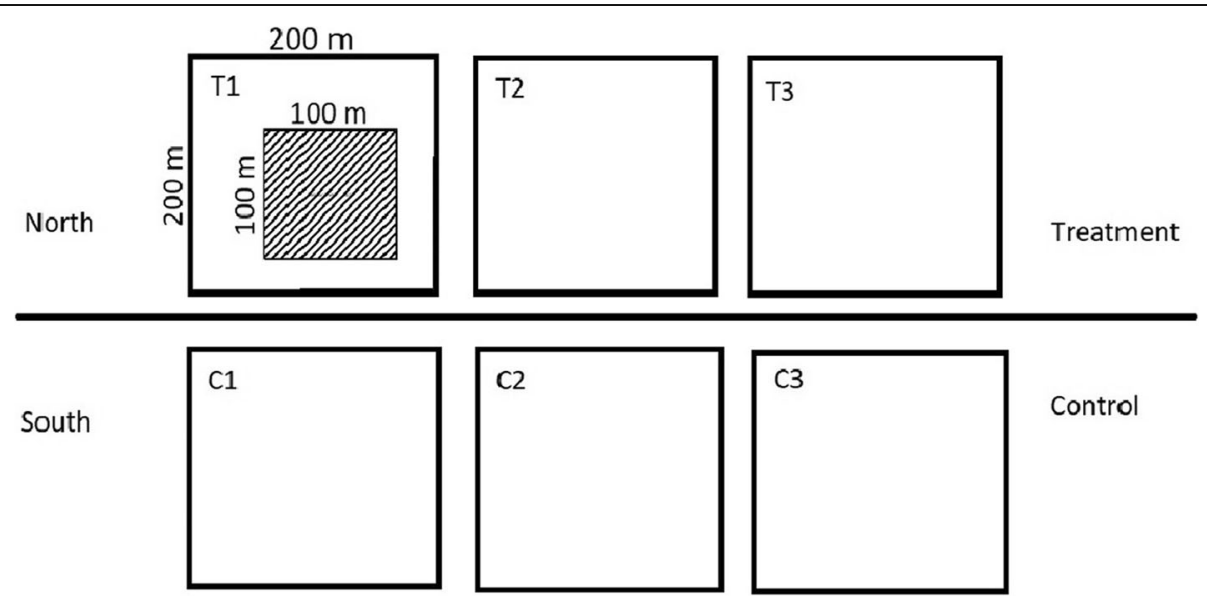

Fig. 3 A schematic overview of the plot and sub-plot design. T1, T2, and T3 represent three treatments: liberation, refinement, and thinning. C1, C2, and C3 represent control sub-plots 
Table 1 Location of permanent sample plots (PSPS), logging years and PSPs measurement years. The Table describes the logging year, first measurement year and the subsequent years of the PSPs measurements after the logging in the PSPs in four different sites

\begin{tabular}{llll}
\hline Sites & Logging year & $\begin{array}{l}\text { First measurement } \\
\text { (years after logging) }\end{array}$ & Measurement year \\
\hline 1 & $1994 / 1995$ & 1 & $1995,1996,1997,1998$, \\
& & & $1999,2001,2007$ \\
2 & $1985 / 1986$ & 11 & $1999,2000,2003,2006$, \\
3 & 2004 & 4 & 2011 \\
4 & 2008 & 5 & $2011,2013,2014$ \\
\hline
\end{tabular}

to trace the missing trees (i.e., mortality of trees) in the datasets of subsequent assessments for a site.

Moreover, we received the records of the volume harvested in the harvested area for the period of 1985-2016 (Table 2). The information on total growing stock for each site was also available for the study (Table 2).

\section{Estimating above-ground biomass}

Above-ground biomass (AGB) for each tree was estimated using Chave et al.'s (2014) Eq. 7 (Eq. 1). The model needs input DBH $(d)$, wood-specific gravity $(\rho)$, and an environmental stress factor $(E)$. $E$ is used to predict AGB of a single tree as input to derive emission factors (EFs) for natural forests. $E$ is a linear function of

Table 2 Volume of timber extracted from the study area for the period 1985-2016. The Table presents the year of harvesting, harvested area and the timber volume extracted

\begin{tabular}{|c|c|c|c|c|c|c|c|}
\hline \multirow[t]{2}{*}{ Year } & \multirow{2}{*}{$\begin{array}{l}\text { Area } \\
\text { (ha) }\end{array}$} & \multicolumn{2}{|c|}{ Volume $\left(\mathrm{m}^{3}\right)$} & \multirow[t]{2}{*}{ Year } & \multirow{2}{*}{$\begin{array}{l}\text { Area } \\
\text { (ha) }\end{array}$} & \multicolumn{2}{|c|}{ Volume $\left(\mathrm{m}^{3}\right)$} \\
\hline & & Total & Per ha & & & Total & Per ha \\
\hline 1985 & 1,100 & $41,592.87$ & 37.81 & 2001 & 1,320 & $48,186.25$ & 36.5 \\
\hline 1986 & 1,199 & $36,916.91$ & 30.79 & 2002 & 1,826 & $53,025.64$ & 29.04 \\
\hline 1987 & 1,104 & $38,010.93$ & 34.43 & 2003 & 1,238 & $45,193.08$ & 36.5 \\
\hline 1988 & 796 & $27,707.04$ & 34.81 & 2004 & 1,233 & $33,033.03$ & 26.79 \\
\hline 1989 & 753 & $31,261.76$ & 41.52 & 2005 & 1,774 & $41,113.47$ & 23.18 \\
\hline 1990 & 900 & $46,020.3$ & 51.13 & 2006 & 1,374 & $48,719.25$ & 35.46 \\
\hline 1991 & 740 & $35,616.05$ & 48.13 & 2007 & 1,466 & $45,204.86$ & 30.84 \\
\hline 1992 & 1,054 & $39,193.93$ & 37.19 & 2008 & 1,440 & $47,739.63$ & 33.15 \\
\hline 1993 & 220 & $8,090.32$ & 36.77 & 2009 & 1,216 & $50,035.89$ & 41.15 \\
\hline 1994 & 1,215 & $37,078.19$ & 30.52 & 2010 & 1,290 & $47,500.58$ & 36.82 \\
\hline 1995 & 1,612 & $66,483.84$ & 41.24 & 2011 & 1,405 & $47,746.96$ & 33.98 \\
\hline 1996 & 1,417 & $59,346.59$ & 41.88 & 2012 & 1,280 & $43,764.52$ & 34.19 \\
\hline 1997 & 1,745 & 73,142 & 41.92 & 2013 & 1,335 & $40,247.18$ & 30.15 \\
\hline 1998 & 931 & $35,903.14$ & 38.56 & 2014 & 9,56 & $33,749.7$ & 35.3 \\
\hline 1999 & 1,429 & $53,036.62$ & 37.11 & 2015 & 579 & $23,142.57$ & 39.97 \\
\hline \multirow[t]{2}{*}{2000} & , 1380 & $45,676.89$ & 33.1 & 2016 & 236 & $10,442.78$ & 44.25 \\
\hline & & & & Total & 37,563 & $13,33,923$ & \\
\hline
\end{tabular}

temperature seasonality, climatic water deficit, and precipitation seasonality, and is available in the form of a global raster map. As the geographic position of the study site was known, the value of $E$ was extracted from the map and was attached to the trees found in the study site. Chave et al. (2014) considered the overestimates in calculation and provide $0.5 \%-6.5 \%$ of bias.

$$
\begin{array}{r}
\mathrm{AGB}_{\text {est }}=\exp [ \\
{[-1.803-0.976 E+0.976 \ln (\rho)} \\
\left.+2.673 \ln (d)-0.0299[\ln (d)]^{2}\right]
\end{array}
$$

where

AGB = total oven-dry above-ground biomass in $(\mathrm{kg})$

$d=$ diameter at breast height $(\mathrm{cm})$

$\rho=$ wood-specific gravity in $\left(\mathrm{g} \cdot \mathrm{cm}^{-3}\right)$

$E=$ environmental factor

There are other calculation models for the region provided by Manuri et al. (2014) and Basuki et al. (2009). Manuri et al. (2014), however, differentiate the equation based on the dipterocarps and non-dipterocarps families while Basuki et al. (2009) present the model for the genera of commercial and mixed species.

\section{Calculating growth-related carbon stock change}

Growth-related carbon stock change relates to carbon accumulation due to biomass growth and is calculated by applying the periodic growth equations proposed by Beers (1962):

$$
G=V_{2}+I-V_{1}-M
$$

where

$G=$ the net growth

$V_{1}=$ volume at first occasion

$V_{2}=$ volume at second occasion

$M=$ mortality

$I$ = ingrowth, or recruitment

\section{Carbon emissions scenarios}

To calculate the carbon emissions caused by selective logging, we used an accounting method proposed by Pearson et al. (2014), which is based on the IPCC's gainloss approach (IPCC 2006). Pearson et al. (2014), provide the estimation of forest degradation emissions using the data from 74 developing countries, which can be considered as the most comprehensive study currently available. The method accounts separately for emissions (i) from the extracted log, (ii) from dead biomass carbon left behind in the gap from felled trees and incidental damage to the surrounding forest, and (iii) from logging 
infrastructure, e.g. skidding trails. The total emission from logging is estimated as the sum of the three sources of emissions.

$$
\mathrm{TE}=\mathrm{ELE}+\mathrm{LDE}+\mathrm{LIE}
$$

where

$\mathrm{TE}=$ total emission resulting from timber harvest $(\mathrm{tC})$

$\mathrm{ELE}=$ extracted log emissions $(\mathrm{tC})$

$\mathrm{LDE}=$ emission from logging damage $(\mathrm{tC})$

LIE $=$ emission related to logging infrastructure

development $(\mathrm{tC})$

ELE is considered a committed emission, meaning that estimated emissions occur fully at the time of the harvest (Pearson et al. 2014). It is related to the volume of timber extracted from the forest and the specific wood gravity, which then gets converted into carbon. LDE occurs where trees are felled and includes both nonutilized biomass of the harvested trees and incidental damages to surrounding forest during felling. LIE results from the logging infrastructure, for example, construction of logging roads, skid trails and logging decks. For calculating ELE, LDE, and LIE, we used the emission factors $\left(\mathrm{tC} \cdot \mathrm{m}^{-3}\right)$ presented by Pearson et al. (2014) for Indonesia: extracted log emissions factor (ELE factor) of 0.25 , logging damage factor (LDF) of 0.57 , and logging infrastructure factor (LIF) of 0.67 .

$$
\begin{aligned}
& \operatorname{ELE}(\mathrm{tC})=0.25\left(\mathrm{tC} \cdot \mathrm{m}^{-3}\right) \times \text { timber extracted }\left(\mathrm{m}^{3}\right) \\
& \operatorname{LDE}(\mathrm{tC})=0.57\left(\mathrm{tC} \cdot \mathrm{m}^{-3}\right) \times \text { timber extracted }\left(\mathrm{m}^{3}\right) \\
& \operatorname{LIE}(\mathrm{tC})=0.67\left(\mathrm{tC} \cdot \mathrm{m}^{-3}\right) \times \text { timber extracted }\left(\mathrm{m}^{3}\right)
\end{aligned}
$$

Emissions associated with logging damages depend on the precaution with which harvesting operations are carried out (Sist and Nguyen-Thé 2002; Feldpausch et al. 2005; Medjibe et al. 2011; Griscom et al. 2014, 2019; Sasaki et al. 2016). We assumed various level of logging damage, which might reflect the transition from conventional logging to reduced impact logging (RIL). In addition to the emission factors presented by Pearson et al. (2014) for logging losses, we increased the corresponding emissions by a factor of two to three:

$$
\operatorname{LDE}_{i}(\mathrm{tC})=(0.57 \times i)\left(\mathrm{tC} \cdot \mathrm{m}^{-3}\right) \times \text { timber extracted }\left(\mathrm{m}^{3}\right)
$$

where, $\mathrm{LDE}_{i}$ is the adjusted logging damage expansion factor and $i$ is an expansion factor with $i=\{1,2,3\}$.
The total emission, $\mathrm{TE}_{i}$, for each scenario, $\mathrm{LDE}_{i}$ is calculated with the equation:

$$
\mathrm{TE}_{i}=\mathrm{ELE}+\mathrm{LDE}_{i}+\mathrm{LIE}
$$

\section{Carbon recovery period}

Carbon recovery period refers to the period needed for the remaining growing stock to be able to compensate the total losses of carbon caused by the timber harvest through growth. The loss of carbon per ha is represented by $\mathrm{TE}_{i}$. The growth of the remaining growing stock is deduced from the PSPs in terms of the periodic annual increment. The periodic annual increment of volume is converted into annual carbon accumulation per ha. This can be used to calculate the time required to compensate for a carbon loss of $\mathrm{TE}_{i}$.

\section{Results}

\section{Extracted timber and carbon emission}

Timber harvesting in the study area follows the TPTI System, which limits the minimum cutting at DBH $(d)$ to $50 \mathrm{~cm}$ for a cutting cycle of 35 years. During the period 1985-2016, an area of 37,563 ha was logged, resulting in the total harvested timber of $1,333,922 \mathrm{~m}^{3}$. On average, 1,174 ha and 41,685 $\mathrm{m}^{3}$ had been logged annually. The average log production for each of the four sites is $34.78,33.36,35.86$ and $33.41 \mathrm{~m}^{3} \cdot \mathrm{ha}^{-1} \cdot$ year $^{-1}$, respectively (Table 3 ).

The extracted timber in those four sites results in extracted log emission (ELE) ranging from 8.34 to $8.69 \mathrm{tC} \cdot \mathrm{ha}^{-}$ 1 and emission from infrastructure (LIE) from 22.35 to $24.03 \mathrm{tC} \cdot \mathrm{ha}^{-1}$. We used three scenarios for logging damage emissions (LDE) (average of four sites); $19.58 \mathrm{tC} \cdot \mathrm{ha}^{-1}$ for scenario $\mathrm{LDE}_{1}, 39.16 \mathrm{tC} \cdot \mathrm{ha}^{-1}$ for scenario $\mathrm{LDE}_{2}$, and 58.74 for $\mathrm{tC} \cdot \mathrm{ha}^{-1}$ for scenario $\mathrm{LDE}_{3}$. The resulting total emissions (average of four sites), $\mathrm{TE}_{i}$, are 51.18, 70.76 and 90.34 tC.ha ${ }^{-1}$, respectively (Table 4 ).

\section{Biomass and carbon growth}

The average annual carbon growth observed is 1.82 $\mathrm{tC} \mathrm{ha}^{-1} \cdot$ year $^{-1}$ (Site 1), $3.55 \mathrm{tC} \cdot \mathrm{ha}^{-1} \cdot \mathrm{year}^{-1}$ (Site 2), 2.08 tC.ha ${ }^{-1} \cdot$ year $^{-1}$ (Site 3), and $4.45 \mathrm{tC} \cdot \mathrm{ha}^{-1} \cdot$ year $^{-1}$ (Site 4).

Carbon growth for the different sites is shown in Fig. 4 and Table 5. The growth of carbon shows a steady increase. However, in Site 1 a decrease in growth can be observed for the period from 1997 to 1999 for treatment refinement and for the period from 1997 to 1998 in all other treatments. This decrease is due to the mortality of individual trees. However, it should be borne in mind that Site 1 covers the longest time series, and thus the growing stock dynamics are considered over much longer periods than for the other three sites. 
Table 3 Average annual log production for the four study sites for the period 1985-2016

\begin{tabular}{|c|c|c|c|}
\hline Site & Forest area (ha) & Total harvested volume (1985-2016) $\left(\mathrm{m}^{3}\right)$ & Average annual log production $\left(\mathrm{m}^{3} \cdot \mathrm{ha}^{-1} \cdot\right.$ year $\left.^{-1}\right)$ \\
\hline Site 1 & 18,745 & 648,065 & 34.78 \\
\hline Site 2 & 18,391 & 606,212 & 33.36 \\
\hline Site 3 & 6,631 & 236,788 & 35.86 \\
\hline Site 4 & 4,976 & 165,508 & 33.41 \\
\hline
\end{tabular}

Average annual carbon growth for the control ranges from $0.52 \mathrm{tC}^{-\mathrm{ha}^{-1}} \cdot \mathrm{year}^{-1}$ (Site 3 Control 2) to $6.90 \mathrm{tC} \cdot \mathrm{ha}^{-}$ ${ }^{1}$.year ${ }^{-1}$ (Site 4 Control 1). For liberation treatment, the annual carbon growth is $1.06,3.07,5.82$, and $6.72 \mathrm{tC}^{-\mathrm{ha}^{-}}$ ${ }^{1}$.year $^{-1}$ for the respective sites with a mean growth of $4.17 \mathrm{tC} \cdot \mathrm{ha}^{-1} \cdot$ year $^{-1}$, which is the highest rate among all treatments and controls. For refinement, the lowest growth was found for Site 1 (1.19 tC.ha $\left.{ }^{-1} \cdot \mathrm{year}^{-1}\right)$, followed by $2.52 \mathrm{tC} \cdot \mathrm{ha}^{-1} \cdot \mathrm{year}^{-1}$ (Site 3), $4.25 \mathrm{tC} \cdot \mathrm{ha}^{-}$ ${ }^{1}$.year ${ }^{-1}$ (Site 2), and $4.30 \mathrm{tC} \cdot \mathrm{ha}^{-1}$.year $^{-1}$ (Site 4) with a mean annual growth across all sites of $3.06 \mathrm{tC} \cdot \mathrm{ha}^{-1} \cdot \mathrm{year}^{-}$

${ }^{1}$. The growth due to thinning ranges from $1.28 \mathrm{tC} \cdot \mathrm{ha}^{-}$ ${ }^{1} \cdot$ year $^{-1}$ (Site 3) to $3.70 \mathrm{tC}^{-h^{-1}}$.year $^{-1}$ (Site 2).

\section{Silvicultural treatment}

Figure 5 shows the growth-related performance of each treatment in the four sites. The average growth over all treatments in all sites ranges from $1.87 \mathrm{tC} \cdot \mathrm{ha}^{-1} \cdot \mathrm{year}^{-1}$ (Control 2) to $4.17 \mathrm{tC} \cdot \mathrm{ha}^{-1} \cdot$ year $^{-1}$ (liberation).

There is no common pattern of growth across the sites. The largest annual carbon growth is found for Control 1 in Site 4. In the other sites, different treatments show the highest and lowest values (Site 1: Control 3 highest, Liberation lowest; Site 2: Control 1 highest, Control 3 lowest; Site 3: Liberation highest, Control 2 lowest) (Table 6).

No statistical difference in carbon growth is found between the treatments, whereas growth between sites are statistically significant (ANOVA, $\alpha=0.05$ ). No significant difference is found for the interaction between treatment and site (Table 7).

\section{Recovery time}

We calculated the time needed for recovering the total carbon emissions from harvesting, including extracted timber and logging losses (Table 3), by assuming the above carbon growth shown in Table 5 .

Under scenario $\mathrm{LDE}_{1}(\mathrm{LDF}=0.57)$, the mean of carbon recovery time ranges from 7 to 104 years with an average of 26 years. When LDF is doubled (Scenario 2) and tripled (Scenario 3), the recovery time increases to $10-143$ years (average $=36$ years) and $13-183$ years (average $=46$ years), respectively. The mean recovery time between sites varies from 13 to 44 years in Scenario 1, 18 to 61 years in Scenario 2, and 24 to 78 years in Scenario 3. Regarding the three silvicultural treatments, liberation requires the shortest recovery time of 20,28 , and 36 years for $\mathrm{LDE}_{1}, \mathrm{LDE}_{2}$, and $\mathrm{LDE}_{3}$, respectively. The longest recovery time is found in Control 2 and ranges from 42 years in $\mathrm{LDE}_{1}$ to 75 years in $\mathrm{LDE}_{3}$ (Table 8).

\section{Discussion}

\section{Harvesting and carbon emission}

The average timber production for each of the four sites ranges between 33.36 and $35.86 \mathrm{~m}^{3} \cdot \mathrm{ha}^{-1} \cdot \mathrm{year}^{-1}$. This is the common average timber production of concessions in the region, which is confirmed by other studies such as Griscom et al. (2014) with the production of 39.1 $\mathrm{m}^{3} \cdot \mathrm{ha}^{-1}$ and Pearson et al. (2014) which range from 26 to $38 \mathrm{~m}^{3} \cdot \mathrm{ha}^{-1}$. They also correspond with production volume of 38.9 observed in Brazil (West et al. 2014). Higher timber production $\left(50-250 \mathrm{~m}^{3} \cdot \mathrm{ha}^{-1} \cdot \mathrm{year}^{-1}\right)$ has been reported by Sist et al. (1998) and Sist et al. (2003a, 2003b), which, however, investigate earlier stages of timber production.

The carbon stock of the four sites studied is estimated to have been between 100 and $173 \mathrm{tC} \cdot \mathrm{ha}^{-1}$ before logging. Measurements started after logging interventions and showed an initial C-stock between 50 and $126 \mathrm{tC} \cdot \mathrm{ha}^{-1}$.

Table 4 Logging harvest and related carbon losses in each site. Related carbon losses are given as ELE= extracted log emission, LIE $=$ emission related to infrastructure, $\mathrm{LDE}=$ emission from logging damage and TE = total emission

\begin{tabular}{|c|c|c|c|c|c|c|c|c|c|}
\hline Site & $\begin{array}{l}\text { Harvest } \\
\left(\mathrm{m}^{3} \cdot \mathrm{ha}^{-1}\right)\end{array}$ & $\begin{array}{l}\text { ELE } \\
\left(\mathrm{tC} \cdot h \mathrm{ha}^{-1}\right)\end{array}$ & $\begin{array}{l}\text { LIE } \\
\left(\mathrm{tC} \cdot \mathrm{ha}^{-1}\right)\end{array}$ & $\begin{array}{l}\mathrm{LDE}_{1} \\
\left(\mathrm{tC} \cdot h \mathrm{ha}^{-1}\right)\end{array}$ & $\begin{array}{l}\mathrm{LDE}_{2} \\
\left(\mathrm{tC} \cdot h \mathrm{ha}^{-1}\right)\end{array}$ & $\begin{array}{l}\mathrm{LDE}_{3} \\
\left(\mathrm{tC} \cdot \mathrm{ha}^{-1}\right)\end{array}$ & $\begin{array}{l}\mathrm{TE}_{1} \\
\left(\mathrm{tC} \cdot \mathrm{ha}^{-1}\right)\end{array}$ & $\begin{array}{l}\mathrm{TE}_{2} \\
\left(\mathrm{tC} \cdot \mathrm{ha}^{-1}\right)\end{array}$ & $\begin{array}{l}\mathrm{TE}_{3} \\
\left(\mathrm{tC} \cdot \mathrm{ha}^{-1}\right)\end{array}$ \\
\hline 1 & 34.779 & 8.69 & 23.30 & 19.82 & 39.65 & 59.47 & 51.82 & 71.64 & 91.47 \\
\hline 2 & 33.356 & 8.34 & 22.35 & 19.01 & 38.03 & 57.04 & 49.70 & 68.71 & 87.73 \\
\hline 3 & 35.859 & 8.96 & 24.03 & 20.44 & 40.88 & 61.32 & 53.43 & 73.87 & 94.31 \\
\hline 4 & 33.406 & 8.35 & 22.38 & 19.04 & 38.08 & 57.12 & 49.78 & 68.82 & 87.86 \\
\hline Mean & 34.35 & 8.58 & 23.16 & 19.58 & 39.16 & 58.74 & 51.18 & 70.76 & 90.34 \\
\hline
\end{tabular}




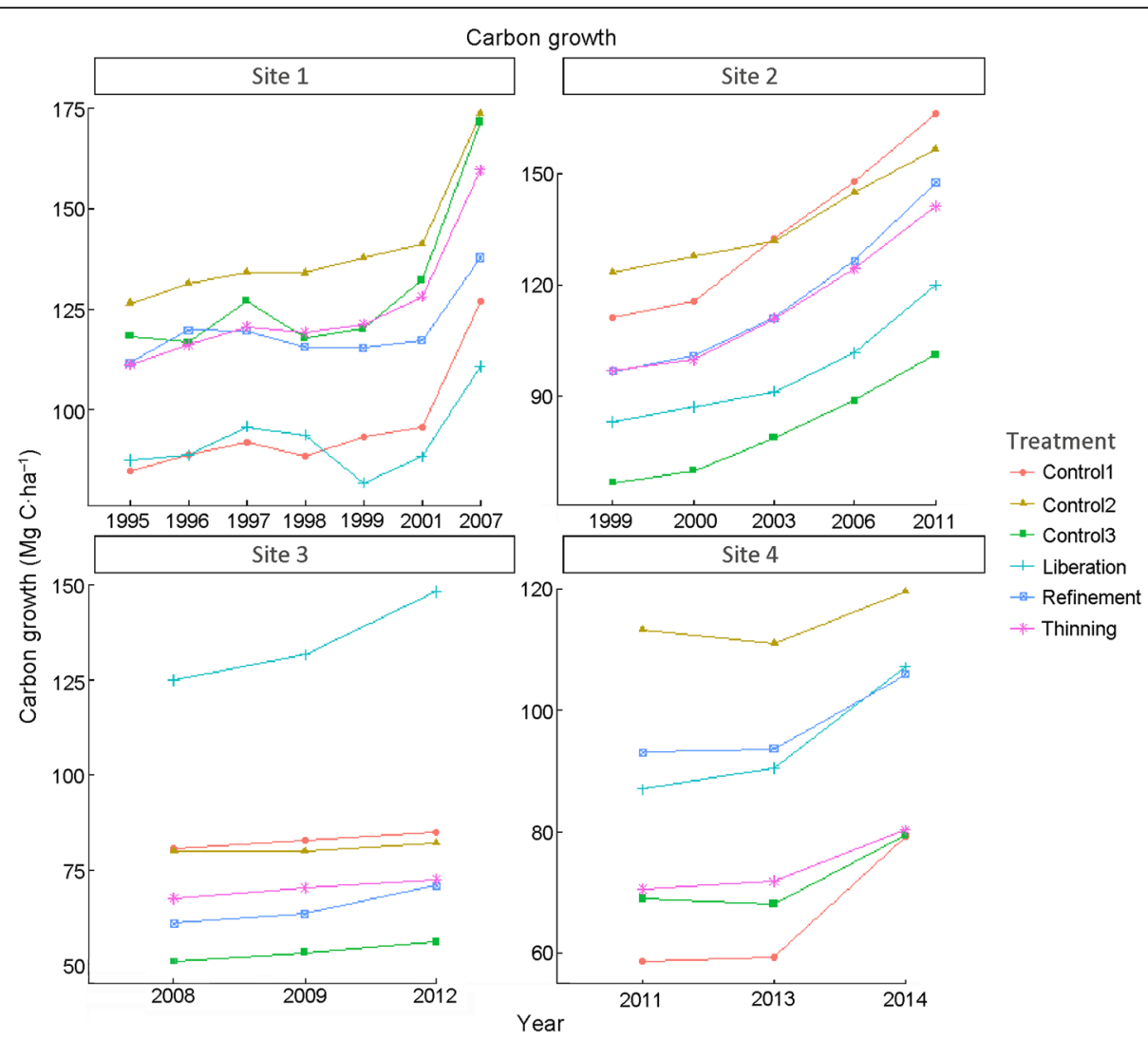

Fig. 4 Carbon stocks estimated in the first measurement years and for the following years based on the subsequent periodic measurements in four different sites $\left(\mathrm{tC} \cdot \mathrm{ha}^{-1}\right)$. The carbon stocks are estimated for four different treatments - liberation, refinement, thinning, and control

Scenario $\mathrm{LDE}_{1}$ is based on the total emission reported by Pearson et al. (2014) that corresponds to common interventions and the resulting emissions from logging, infrastructure, and logging losses in the region. Those emissions from the four different sites studied range from 49 to $53 \mathrm{tC} \cdot \mathrm{ha}^{-1}$, with an average of $51.18 \mathrm{tC} \cdot \mathrm{ha}^{-1}$. Cstock before logging and related C-stock losses by harvesting are comparable to magnitudes reported by Sasaki et al. (2016), which report $172.5\left( \pm 16.8 \mathrm{tC} \cdot \mathrm{ha}^{-1}\right)$ for the initial $\mathrm{C}$-stock and losses of $52.2 \mathrm{tC} \cdot \mathrm{ha}^{-1}$. Between the four sites studied, no significant difference in emission was found. Scenario $\mathrm{LDE}_{1}$ is conservative by assuming comparatively low forest harvesting emissions.

Larger logging losses (Bertault and Sist 1997; Chapman and Chapman 1997; Sist and Nguyen-Thé 2002; Priyadi et al. 2005 Pinard and Putz 2006; Medjibe et al. 2011) and logging intensities (Sist et al. 1998; Sist et al. 2003a, 2003b; Bischoff et al. 2005) are reported for the Kalimantan. To understand the magnitude of the potential carbon emissions associated with larger logging losses, the study defined additional scenarios that anticipate emissions that exceed the emissions of the conservative Scenario 1. Scenarios $\mathrm{LDE}_{2}$ and $\mathrm{LDE}_{3}$ assume larger logging intensities and larger harvesting-related carbon losses. Scenario 2 assumes two times higher logging damage (LDE), while Scenario 3 assumes three times higher LDE than the LDE in Scenario 1. Under these scenarios, the total C-losses per hectare increase to 70.76 and $90.34 \mathrm{tC} \cdot \mathrm{ha}^{-1}$ (138\% and $176 \%$ of Scenario 1).

The scenarios and associated findings suggested that unsustainable and destructive harvesting practice severely undermine sustainable forest management (SFM). On the one hand, low-or reduced-impact logging, characterized by less dead biomass carbon left behind gaps created by felled trees and reduced incidental damage to the surrounding forest, brings significant ecological benefit including reduced carbon emissions. On the other hand, leaving less biomass behind the forest means a higher timber recovery rate can be realized. Therefore, the intensity and the way of timber harvesting are crucial factors to influence SFM.

\section{Regrowth}

The growth observed for the four sites and different silvicultural treatments showed no uniform pattern and ranged between 1.65 and $4.61 \mathrm{tC} \cdot \mathrm{ha}^{-1} \cdot \mathrm{year}^{-1}$. In other studies, conducted in Kalimantan, increases in C-stock of $4.5 \pm 1.5 \mathrm{tC} \cdot \mathrm{ha}^{-1} \cdot$ year $^{-1}$ (Mazzei et al. 2010; Poorter et al. 2016) or in aboveground wood production of $6.3 \mathrm{Mg}$ 
Table 5 Average growth of diameter (d), basal area (G), biomass, and carbon (C) by site and treatment

\begin{tabular}{|c|c|c|c|c|c|}
\hline \multirow[t]{2}{*}{ Site } & \multirow[t]{2}{*}{ Treatment } & \multicolumn{4}{|c|}{ Annual increment/growth } \\
\hline & & $d\left(\mathrm{~cm} \cdot\right.$ year $\left.^{-1}\right)$ & $G\left(m^{2} \cdot\right.$ ha $^{-1} \cdot$ year $\left.^{-1}\right)$ & Biomass (t.ha ${ }^{-1}$.year ${ }^{-1}$ ) & C (t.ha ${ }^{-1} \cdot$ year $\left.^{-1}\right)$ \\
\hline 1 & Liberation & 0.12 & 0.15 & 2.16 & 1.06 \\
\hline 1 & Refinement & 0.11 & 0.19 & 2.42 & 1.19 \\
\hline 1 & Thinning & 0.15 & 0.37 & 4.48 & 2.20 \\
\hline 1 & Control1 & 0.09 & 0.36 & 3.88 & 1.90 \\
\hline 1 & Control2 & 0.16 & 0.37 & 4.38 & 2.14 \\
\hline \multirow[t]{2}{*}{1} & Control3 & 0.13 & 0.44 & 4.94 & 2.42 \\
\hline & Mean & 0.13 & 0.31 & 3.71 & 1.82 \\
\hline 2 & Liberation & 0.29 & 0.61 & 6.26 & 3.07 \\
\hline 2 & Refinement & 0.33 & 0.79 & 8.68 & 4.25 \\
\hline 2 & Thinning & 0.23 & 0.69 & 7.56 & 3.70 \\
\hline 2 & Control1 & 0.28 & 0.84 & 9.39 & 4.60 \\
\hline 2 & Control2 & 0.26 & 0.55 & 5.67 & 2.78 \\
\hline \multirow[t]{2}{*}{2} & Control3 & 0.30 & 0.60 & 5.87 & 2.88 \\
\hline & Mean & 0.28 & 0.68 & 7.24 & 3.55 \\
\hline 3 & Liberation & -0.06 & 1.20 & 11.88 & 5.82 \\
\hline 3 & Refinement & 0.02 & 0.57 & 5.13 & 2.52 \\
\hline 3 & Thinning & -0.13 & 0.31 & 2.55 & 1.25 \\
\hline 3 & Control1 & 0.17 & 0.18 & 2.28 & 1.12 \\
\hline 3 & Control2 & -0.01 & 0.05 & 1.05 & 0.52 \\
\hline \multirow[t]{2}{*}{3} & Control3 & 0.13 & 0.30 & 2.60 & 1.28 \\
\hline & Mean & 0.02 & 0.44 & 4.25 & 2.08 \\
\hline 4 & Liberation & 0.34 & 1.91 & 13.72 & 6.72 \\
\hline 4 & Refinement & 0.00 & 1.17 & 8.77 & 4.30 \\
\hline 4 & Thinning & 0.69 & 0.78 & 6.64 & 3.25 \\
\hline 4 & Control1 & 0.52 & 2.48 & 14.08 & 6.90 \\
\hline 4 & Control2 & -0.13 & 0.64 & 4.20 & 2.06 \\
\hline \multirow[t]{2}{*}{4} & Control3 & 0.07 & 0.79 & 7.11 & 3.48 \\
\hline & Mean & 0.25 & 1.29 & 9.09 & 4.45 \\
\hline
\end{tabular}

dry mass per ha per year (Banin et al. 2014) are reported. Values equivalent to or slightly higher than the values of our study have been found in other tropical forests in Sabah (1.4 tC.ha ${ }^{-1} \cdot$ year $\left.^{-1}\right)$, Southern Mexico, Brazil (0.5 $\mathrm{tC} \cdot \mathrm{ha}^{-1} \cdot \mathrm{year}^{-1}$ for conventional logging and $2.8 \mathrm{tC} \cdot \mathrm{ha}^{-}$ ${ }^{1} \cdot$ year $^{-1}$ for RIL), and Suriname $\left(0.64 \mathrm{tC} \cdot \mathrm{ha}^{-1} \cdot \mathrm{year}^{-1}\right)$ (Lobo et al. 2007; Berry et al. 2010; Aryal et al. 2014; West et al. 2014; Roopsind et al. 2017).

We found no significant differences between the treatments applied, but of the four sites $(\alpha=0.1)$, Site 4 showed the highest growth and Site 1 the lowest. The time after logging covers four years in Site 4 and 12 years in Site 1. Figueira et al. (2008) describe the impact of light availability on growth. This effect is particularly strong shortly after interventions. Considering that the levels of logging interventions are about the same in the four sites, we presume that the differences in growth are not only due to specific local site conditions, but they may also depend on the time under consideration after interventions.

\section{Effects of silvicultural treatments}

Silvicultural treatment is often seen as a controlling element of stand growth (Graaf 1986; Lamprecht 1989). However, in our study silvicultural treatments do not significantly influence the forest stand growth. For example, liberation, which is a light silvicultural treatment, shows the largest average growth over all treatments and site combinations $\left(4.17 \mathrm{tC} \cdot \mathrm{ha}^{-1} \cdot \mathrm{year}^{-1}\right)$ but the lowest growth in Site 1. Even between controls, where no treatments are applied, the performance with respect to growth shows considerable contrasts between the four sites.

Each treatment shows a different behavior in the four sites. Since a mix-up between the growth implications of 


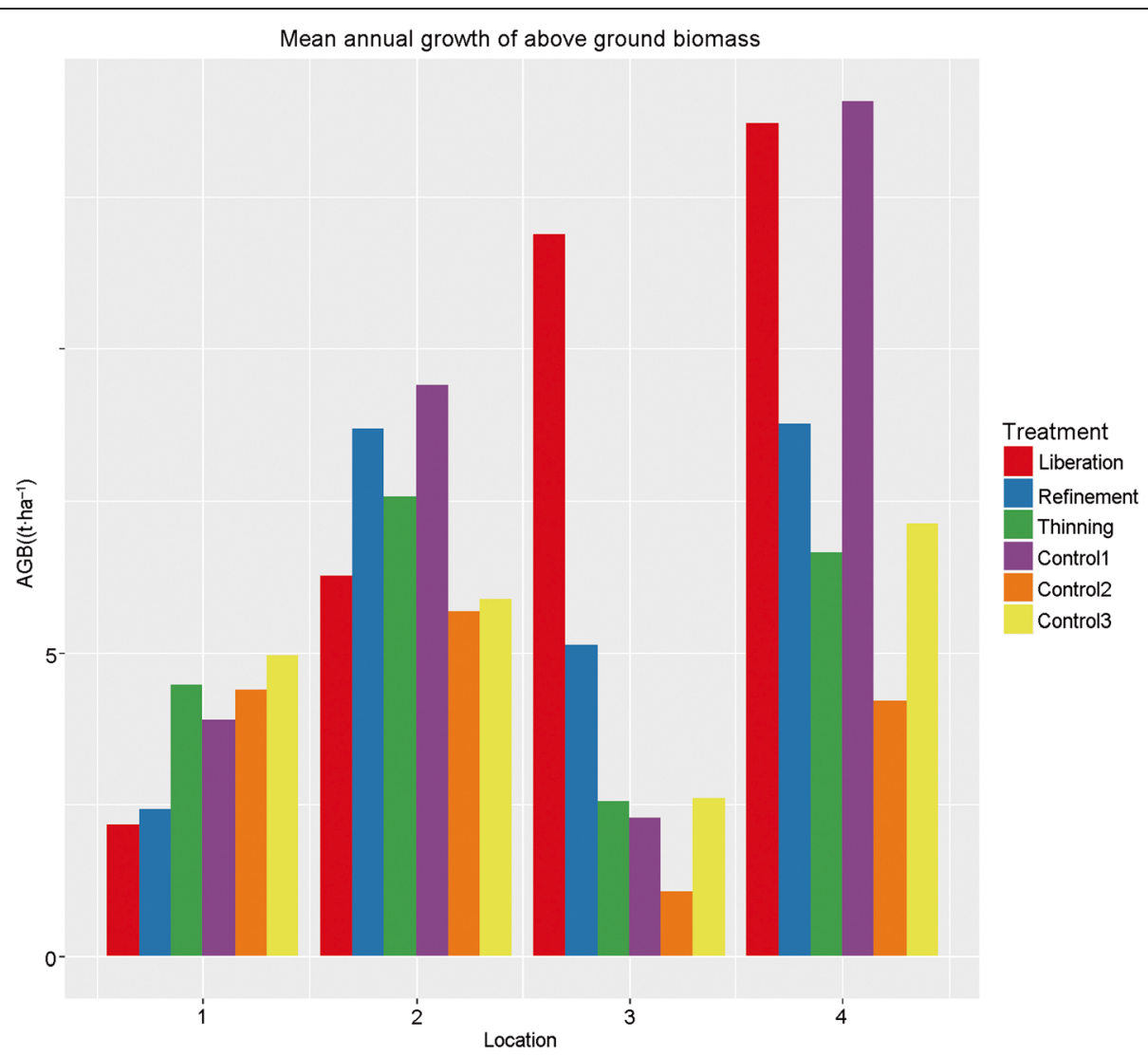

Fig. 5 Mean annual growth of aboveground biomass at four study sites $\left(\mathrm{tC} \cdot \mathrm{h} \mathrm{a}^{-1}\right)$. The carbon stocks are estimated for four different treatments-liberation, refinement, thinning, and control

the individual treatments and the period under consideration cannot be excluded, statements about the influence of silvicultural treatments on forest growth are only possible with reservations. The lack of impact of treatment on forest growth is also confirmed by our statistical analysis, which shows no significance.

These findings stand in contrast to other studies, which found at least moderate treatment effects (Forshed et al. 2008; Peña-Claros et al. 2008; Villegas et al. 2009). Krisnawati and Wahjono (2010) describe a positive influence of purposive liberation of future crop trees. The stimulating effect of silvicultural treatment on individual tree growth was observed

Table 6 Mean carbon growth by site and treatment $\left(\mathrm{tC} \cdot \mathrm{ha}^{-1} \cdot\right.$ year $\left.^{-1}\right)$

\begin{tabular}{llllll}
\hline Treatment/Site & Site 1 & Site 2 & Site 3 & Site 4 & Treatment mean \\
\hline Liberation & 1.06 & 3.07 & 5.82 & 6.72 & 4.17 \\
Refinement & 1.19 & 4.25 & 2.52 & 4.30 & 3.06 \\
Thinning & 2.20 & 3.70 & 1.25 & 3.25 & 2.60 \\
Control1 & 1.90 & 4.60 & 1.12 & 6.90 & 3.63 \\
Control2 & 2.14 & 2.78 & 0.52 & 2.06 & 1.87 \\
Control3 & 2.42 & 2.88 & 1.28 & 3.48 & 2.51 \\
\hline
\end{tabular}

after a period of 20 years by de Graaf et al. (1999). Our results, as well as those from other studies, suggest that post-harvest stand growth depends more on the condition of the remaining stand than on the silvicultural treatment. This view is also shared by other authors (Chapman and Chapman 1997; Bonnell et al. 2011; Sist et al. 2003a, 2003b; West et al. 2014).

\section{Recovery time}

An estimation of the recovery time facilitates an overall assessment of carbon emissions from harvesting and carbon removals due to the growth of the remaining stand. It is thus an important indicator for SFM. A recovery time of more than 100 years was found for logged stands in Mexico (Aryal et al. 2014) and Africa (Bonnell et al. 2011). In studies carried out in other tropical forests,

Table 7 Analysis of variance (ANOVA)

\begin{tabular}{|c|c|c|c|c|c|}
\hline & Df & Sum Sq & Mean Sq & $F$ value & $\operatorname{Pr}(>F)$ \\
\hline Treatment & 5 & 57.03 & 11.41 & 1.418 & 0.2738 \\
\hline loc & 3 & 116.20 & 38.73 & 4.816 & $0.0153^{*}$ \\
\hline Residuals & 15 & 120.65 & 8.04 & & \\
\hline Signif. codes & \multicolumn{5}{|c|}{$0^{\prime * * * \prime}, 0.001^{\prime * * \prime}, 0.01^{* * \prime}, 0.05^{\prime \prime}, 0.1 *, 1$} \\
\hline
\end{tabular}


Table 8 Carbon emissions and recovery time under three scenarios

\begin{tabular}{|c|c|c|c|c|c|c|c|c|c|}
\hline \multirow[t]{2}{*}{ Site } & \multirow[t]{2}{*}{ Treatment } & \multirow{2}{*}{$\begin{array}{l}\text { Annual } \\
\text { Carbon } \\
\text { Growth } \\
\left(\mathrm{tC}^{-} \mathrm{ha}^{-1} \cdot \text { year }^{-1}\right)\end{array}$} & \multirow[t]{2}{*}{$\begin{array}{l}\text { Harvest } \\
\left(\mathrm{m}^{3} \cdot h \mathrm{~h}^{-1}\right)\end{array}$} & \multicolumn{3}{|c|}{$\begin{array}{l}\text { Total emission } \\
\left(\mathrm{tC} \cdot \mathrm{ha}^{-1}\right)\end{array}$} & \multicolumn{3}{|c|}{$\begin{array}{l}\text { Recovery Time } \\
\text { (years) }\end{array}$} \\
\hline & & & & $\mathrm{TE}_{1}$ & $\mathrm{TE}_{2}$ & $\mathrm{TE}_{3}$ & $\mathrm{TR}_{1}$ & $\mathrm{TR}_{2}$ & $\overline{T^{2}}$ \\
\hline 1 & Liberation & 1.06 & 34.78 & 51.82 & 71.65 & 91.47 & 49 & 68 & 86 \\
\hline 1 & Refinement & 1.19 & 34.78 & 51.82 & 71.65 & 91.47 & 44 & 60 & 77 \\
\hline 1 & Thinning & 2.20 & 34.78 & 51.82 & 71.65 & 91.47 & 24 & 33 & 42 \\
\hline 1 & Control1 & 1.90 & 34.78 & 51.82 & 71.65 & 91.47 & 27 & 38 & 48 \\
\hline 1 & Control2 & 2.14 & 34.78 & 51.82 & 71.65 & 91.47 & 24 & 33 & 43 \\
\hline \multirow[t]{2}{*}{1} & Control3 & 2.42 & 34.78 & 51.82 & 71.65 & 91.47 & 21 & 30 & 38 \\
\hline & Loc1. Mean & & & & & & 32 & 44 & 56 \\
\hline 2 & Liberation & 3.07 & 33.36 & 49.71 & 68.72 & 87.74 & 16 & 22 & 29 \\
\hline 2 & Refinement & 4.25 & 33.36 & 49.71 & 68.72 & 87.74 & 12 & 16 & 21 \\
\hline 2 & Thinning & 3.70 & 33.36 & 49.71 & 68.72 & 87.74 & 13 & 19 & 24 \\
\hline 2 & Control1 & 4.60 & 33.36 & 49.71 & 68.72 & 87.74 & 11 & 15 & 19 \\
\hline 2 & Control2 & 2.78 & 33.36 & 49.71 & 68.72 & 87.74 & 18 & 25 & 32 \\
\hline \multirow[t]{2}{*}{2} & Control3 & 2.88 & 33.36 & 49.71 & 68.72 & 87.74 & 17 & 24 & 30 \\
\hline & Loc2. Mean & & & & & & 15 & 20 & 26 \\
\hline 3 & Liberation & 5.82 & 35.86 & 53.43 & 73.87 & 94.31 & 9 & 13 & 16 \\
\hline 3 & Refinement & 2.52 & 35.86 & 53.43 & 73.87 & 94.31 & 21 & 29 & 37 \\
\hline 3 & Thinning & 1.25 & 35.86 & 53.43 & 73.87 & 94.31 & 43 & 59 & 75 \\
\hline 3 & Control1 & 1.12 & 35.86 & 53.43 & 73.87 & 94.31 & 48 & 66 & 84 \\
\hline 3 & Control2 & 0.52 & 35.86 & 53.43 & 73.87 & 94.31 & 104 & 143 & 183 \\
\hline \multirow[t]{2}{*}{3} & Control3 & 1.28 & 35.86 & 53.43 & 73.87 & 94.31 & 42 & 58 & 74 \\
\hline & Loc3. Mean & & & & & & 44 & 61 & 78 \\
\hline 4 & Liberation & 6.72 & 33.41 & 49.78 & 68.82 & 87.87 & 7 & 10 & 13 \\
\hline 4 & Refinement & 4.30 & 33.41 & 49.78 & 68.82 & 87.87 & 12 & 16 & 20 \\
\hline 4 & Thinning & 3.25 & 33.41 & 49.78 & 68.82 & 87.87 & 15 & 21 & 27 \\
\hline 4 & Control1 & 6.90 & 33.41 & 49.78 & 68.82 & 87.87 & 7 & 10 & 13 \\
\hline 4 & Control2 & 2.06 & 33.41 & 49.78 & 68.82 & 87.87 & 24 & 33 & 43 \\
\hline \multirow[t]{5}{*}{4} & Control3 & 3.48 & 33.41 & 49.78 & 68.82 & 87.87 & 14 & 20 & 25 \\
\hline & Loc4. Mean & & & & & & 13 & 18 & 24 \\
\hline & Mean & & & & & & 26 & 36 & 46 \\
\hline & Minimum & & & & & & 7 & 10 & 13 \\
\hline & Maximum & & & & & & 104 & 143 & 183 \\
\hline
\end{tabular}

recovery rates between 16 and 30 years were described (Mazzei et al. 2010; West et al. 2014; Poorter et al. 2016; Raymond et al. 2015).

Under scenario $\mathrm{LDE}_{1}$, we found an average recovery time of 26 years, which is shorter than the cutting cycle of 35 years mandatory in Indonesia. However, the wide range of recovery time under scenario $\mathrm{LDE}_{1}$, which extends from 7 to 104 years, leaves large uncertainties. In Scenarios $\mathrm{LDE}_{2}$ and $\mathrm{LDE}_{3}$, the recovery times are correspondingly longer, which might be due to higher losses by logging damage and extend beyond the Indonesian cutting cycle. Martin et al. (2015) conducted a meta- analysis to study at what age following forest clearance carbon pools in secondary tropical forests reach equivalent values to those of undisturbed forests. They found that above-ground carbon pool recovered within 85 years, and that soil carbon remained largely unchanged over time. In our findings, the longer recovery period for $\mathrm{LDE}_{2}$ and $\mathrm{LDE}_{3}$ scenarios supports the findings of Martin et al. (2015).

Losses due to extracted timber, logging residuals, and infrastructure measures thus have a decisive impact on the recovery time. Timber harvesting measures that are not carried out gently need recovery periods that are 
longer than the usual harvesting cycles. Therefore, forests cannot recover before the next harvesting intervention, leading to long-term losses of biomass and C-stocks and thus to forest degradation.

Sustainability is the goal of forest management. Sustainable forest management means the balance of ecological, economic, and sociocultural function of forests for present and future generations. It implies that the need for longrun growing $\mathrm{C}$-stock maintenance to recover the biomass losses. Unsustainable forest management occurs when biomass loss from growing stock cannot be recovered by the growth of the remaining stand. Our study shows that the amount of timber extracted does not suffice to make statements about the time needed to recover the growing stock and the C-stock.

Of crucial importance is the amount of biomass and carbon losses caused by harvest residuals and infrastructure measures. In general, these quantities are of no economic significance and at best reduce the costs of wood harvesting operations. Therefore, these influencing components must be given a greater importance, e.g. through timber harvesting guidelines or financial incentives to reduce the amount of timber felled but not used.

\section{REDD+ mechanism and harvesting losses}

Indonesia is participating in the REDD+ mechanism. One of the five activities of the REDD+ mechanism includes reducing emissions from forest degradation (Decision 1 of the 16th session of the Conference of the Parties to the UNFCCC (decision1/CP.16)). To achieve the goal of the REDD+ mechanism, reducing logging losses from logging damage and logging infrastructure development through the implementation of improved harvesting and /or RIL is crucial. At the same time, a country might decide to reduce timber harvesting in order to reduce forest degradation and consequently reduction in forest carbon emissions. In this case, a reduction in harvest intensity leads to a reduction in revenues from timber harvesting. Considerable investments are needed to design and implement measures like RIL and might impose a high economic burden to the country in the initial years of REDD+ implementation. The forgone benefits and investment might exceed the REDD+ revenues generated from accountable carbon credits (emission reductions). However, the realization of long-term financial and ecological benefits of RIL and other cobenefits of the REDD+ mechanism encourages adopting such measures. Improved harvesting practices and RIL stimulates the accomplishment of sustainable management of forests, which is another designated REDD+ activity (decision1/CP.16). For C-stock dynamics, the improved harvesting and/or RIL even play a greater role by reducing the carbon recovery period than the biomass growth after conventional harvesting interventions
(See 'Regrowth' section of this Chapter). As a result, measures to reduce harvesting losses account for a greater, if not the most important, share of sustainable forest management within the scope of REDD+.

\section{Conclusions}

This study has analyzed the rate of above-ground biomass and carbon recovery in post-logging secondary forests managed by a forest concession holder in East Kalimantan, Indonesia. The study has shown that above-ground carbon pool may take only 26 years to recover following selective logging. In secondary forests undergoing highintensity logging associated with larger incidental damage, above-ground carbon pool takes a longer time to reach equivalent values to those of unlogged forests.

This study provides new information regarding the recovery of above-ground carbon pools after selective logging for policy and forest management entities including forest concessions holder and forest management units. Such information has increasing relevance in the context of climate change mitigation polices designed to reduce carbon emissions from forest degradation such as REDD+.

Future discussions concerning the reduction of intervention cycles can only be conducted against the background of the losses of the remaining stock caused by logging. Our study shows that arbitrarily determined intervention cycles of 30 years, which is currently applied in some sites in Kalimantan, is very risky in terms of biomass and carbon recovery. Owing to the wide growth performance after logging interventions, site-specific specifications of intervention cycles are necessary. An important influencing factor is the amount of biomass losses from previous cutting operations. This calls for mandatory reduced impact logging and specific management regimes instead of uniform annual allowable cut.

In our study, silvicultural treatments, i.e. liberation, refinement, and thinning, do not significantly influence forest stand growth. This does not mean that we argue in favor of passive restoration of tropical forests. Further research is needed to explore the impacts of such silvicultural treatments on biomass recovery.

Our study did not show the impact of carbon storage of harvested wood products or emission reductions by the material and energetic use of timber. Butarbutar et al. (2016) showed that carbon offsets by timber utilization are a major component of the C-balance of logging interventions. However, only reduced impact logging that minimizes logging residuals and losses by infrastructure offers the possibility for carbon offsets.

\section{Abbreviations}

AGB: Above-ground biomass; d: Diameter at breast height $(130 \mathrm{~cm})$;

ELE: Extracted log emission (tC); LDE: Emission from logging damage (tC); LIE: Emission related to logging infrastructure development (tC); TE: Total emission resulting from timber harvest (tC) 


\section{Acknowledgements}

We gratefully acknowledge Georg Buchholz of GIZ Forest and Climate Change Program for providing continuous support to this study. Data collection was performed with the support of PT. Gunung Gajah Abadi. We would like to express our deepest gratitude to Mr. Totok Suripto, Director of PT. Gunung Gajah, and his research and development staff involved in this activity. We are thankful to Dr. Archana Gauli for proof reading of the manuscript. We thank MINGSInternational, University of Hamburg for supporting professional proof reading/language correction for the early draft of the manuscript.

\section{Authors' contributions}

TB, MK and PN designed the research. TB and SS worked on data preparation and TB and MK performed data analysis. TB, MK, SS, and PN drafted the article. TB, MK and PN reviewed the drafts. All authors read and approved the final manuscript.

\section{Funding}

Not applicable.

\section{Availability of data and materials}

The datasets used and/or analyzed during the current study are available from the corresponding author on reasonable request.

\section{Ethics approval and consent to participate} Not Applicable.

\section{Consent for publication}

Not Applicable.

\section{Competing interests}

The authors declare that they have no competing interests.

\section{Author details}

${ }^{1} \mathrm{GIZ}$ Forest and Climate Change Program, Manggala Wanabakti Bd. Block VII FI. 6, J. Gatot Subroto, Jakarta 10270, Indonesia. ${ }^{2}$ University of Hamburg, World Forestry, Leuschnerstr. 91, D-21031 Hamburg, Germany. ${ }^{3}$ University of Mulawarman, Faculty of Forestry, Gunung Kelua, Indonesia. ${ }^{4}$ SURF, Leuschnerstr. 91, D-21031 Hamburg, Germany. ${ }^{5}$ Friends of Nature (FON Nepal), Kathmandu, Nepal.

Received: 4 December 2018 Accepted: 8 July 2019

Published online: 02 September 2019

\section{References}

Adelaine Michela e S. Figueira, Scott D. Miller, Cleilim Albert D. de Sousa, Mary C. Menton, Augusto R. Maia, Humberto R. da Rocha, Michael L. Goulden, (2008). Effects of selective logging on tropical forest tree growth. Journal of Geophysical Research: Biogeosciences 113 (G1):n/a-n/a.

Anonim (1995) Keputusan Menteri Kehutanan. No. 237/Kpts-II/95. Tentang Pemantauan Pertumbuhan Riap Tegakan Hutan

Aryal DR, De Jong BHJ, Ochoa-Gaona S, Esparza-Olguin L, Mendoza-Vega J (2014) Carbon stocks and changes in tropical secondary forests of southern Mexico. Agr Ecosyst Environm 195:220-230 http://www.sciencedirect.com/science/ article/pii/S0167880914003259. Accessed 01 Dec 2018

Baccini A, Walker W, Carvalho L, Farina M, Sulla-Menashe D, Houghton RA (2017) Tropical forests are a net carbon source based on aboveground measurements of gain and loss. Science 358(6360):230-234

Basuki TM, van Laake PE, Skidmore AK, Hussin YA (2009) Allometric equations for estimating the above-ground biomass in tropical lowland dipterocarp forests. Forest Ecol Manag 257(8):1684-1694

Beers TW (1962) Component of forest growth. J Forest 60(4):245-248

Berry NJ, Phillips OL, Lewis SL, Hill JK, Edwards DP, Tawatao NB, Ahmad N, Magintan D, Khen CV, Maryati M, Ong RC, Hamer KC (2010) The high value of logged tropical forests: lessons from northern Borneo. Biodivers Conserv 19(4):985-997 http://link.springer.com/10.1007/s10531-010-9779-z. Accessed 06 May 2017

Bertault J, Sist P (1997) An experimental comparison of different harvesting intensities with reduced-impact and conventional logging in East Kalimantan, Indonesia. Forest Ecol Manag 94(1-3):209-218
Bischoff W, Newbery DA, Lingenfelder M, Schnaeckel R, Petol GH, Madani L, Ridsdale CE (2005) Secondary succession and dipterocarp recruitment in Bornean rain forest after logging. Forest Ecol Manag 218(1-3):174-192 http://www.sciencedirect.com/ science/article/pii/S0378112705004603. Accessed 14 March 2016

Blanc L, Echard M, Herault B, Bonal D, Marcon E, Chave J, Baraloto C (2009) Dynamics of aboveground carbon stocks in a selectively logged tropical forest. Ecol Appl 19(6):1397-1404 http://doi.wiley.com/10.1890/08-1572.1. Accessed 25 April 2017

Blaser J, Sarre A, Poore D, Johnson S (2011) Technical series status of tropical forest management 2011. ITTO Tecnical series no. 38. Yokohama, Japan

Bonnell TR, Reyna-Hurtado R, Chapman CA (2011) Post-logging recovery time is longer than expected in an east African tropical forest. Forest Ecol Manag 261 (4):855-864. https://www.sciencedirect.com/science/article/pii/S0378112 71000719X. Accessed 25 April 2017

Budiaman A, Pradata AA (2014) Low impact felling distance and allowable number of felled trees in tpti system. Jurnal Manajemen Hutan Tropika (J Trop Forest Manag) 19(3):194-200

Chapman CA, Chapman LJ (1997) Forest regeneration in logged and unlogged forests of Kibale National Park, Uganda. Biotropica 29(4):396-412 http://doi. wiley.com/10.1111/j.1744-7429.1997.tb00035.x. Accessed 25 April 2017

de Graaf NR, Poels RLH, Rompaey RSARV (1999) Effect of silvicultural treatment on growth and mortality of rainforest in Surinam over long periods. Forest Ecol Manag 124(2-3):123-135. https://www.sciencedirect.com/science/article/ pii/S0378112799000572. Accessed 25 April 2017

DeFries RS, Houghton RA, Hansen MC, Field CB, Skole D, Townshend J (2002) Carbon emissions from tropical deforestation and regrowth based on satellite observations for the 1980s and 1990s. PNAS 99(22):14256-14261 http://www.ncbi.nlm.nih.gov/pubmed/12384569. Accessed 25 April 2017

Feldpausch TR, Jirka S, Passos CAM, Jasper F, Riha SJ (2005) When big trees fall: damage and carbon export by reduced impact logging in southern Amazonia. Forest Ecol Manag 219(2-3):199-215

Forshed O, Karlsson A, Falck J, Cedergren J (2008) Stand development after two modes of selective logging and pre-felling climber cutting in a dipterocarp rainforest in Sabah, Malaysia. Forest Ecol Manag 255(3-4):993-1001

Gourlet-Fleury S, Mortier F, Fayolle A, Baya F, Ouedraogo D, Benedet F, Picard N (2013) Tropical forest recovery from logging: a 24 year silvicultural experiment from Central Africa. Philos T R Soc B 368(1625):20120302 http:// www.ncbi.nlm.nih.gov/pubmed/23878332. Accessed 25 April 2017

Graaf, Nicolaus Reitze de (1986) A silvicultural system for natural regeneration of tropical rain forest in Suriname/Wageningen: Landbouwhogeschool. Proefschrift Wageningen. ISBN 90-9001239-7. Agricultural University, Wageningen, 1986.

Griscom B, Ellis P, Putz FE (2014) Carbon emissions performance of commercial logging in East Kalimantan, Indonesia. Global Chang Biol 20(3):923-937. https://doi.org/10.1111/gcb.12386 Accessed 25 April 2017

Griscom BW, Ellis PW, Burivalova Z, Halperin J, Marthinus D, Runting RK, Ruslandi SD, Putz FE (2019) Reduced-impact logging in borneo to minimize carbon emissions and impacts on sensitive habitats while maintaining timber yields. Forest Ecol Manag 438(February):176-185. https://doi.org/10.1016/j.foreco.201 9.02.025 Accessed 25 April 2017

Haruni Krisnawati, Djoko Wahjono, (2010) Effect of Post-Logging Silvicultural Treatment on Growth Rates of Residual Stand in a Tropical Forest. Indonesian Journal of Forestry Research 7(2):112-124.

Hawthorne WD, Sheil D, Agyeman VK, Abu Juam M, Marshall CAM (2012) Logging scars in Ghanaian high forest: towards improved models for sustainable production. Forest Ecol Manag 271:27-36. https://doi.org/10.1 016/j.foreco.2012.01.036 Accessed 25 April 2017

Houghton RA, Byers B, Nassikas AA (2015) A role for tropical forests in stabilizing atmospheric $\mathrm{CO}_{2}$. Nat Climat Change 5(12):1022-1023 http://www.nature. com/doifinder/10.1038/nclimate2869. Accessed 25 April 2017

Jérôme Chave, Maxime Réjou-Méchain, Alberto Búrquez, Emmanuel Chidumayo, Matthew S. Colgan, Welington B.C. Delitti, Alvaro Duque, Tron Eid, Philip M. Fearnside, Rosa C. Goodman, Matieu Henry, Angelina Martínez-Yrízar, Wilson A. Mugasha, Helene C. Muller-Landau, Maurizio Mencuccini, Bruce W. Nelson, Alfred Ngomanda, Euler M. Nogueira, Edgar Ortiz-Malavassi, Raphaël Pélissier, Pierre Ploton, Casey M. Ryan, Juan G. Saldarriaga, Ghislain Vieilledent, (2014) Improved allometric models to estimate the aboveground biomass of tropical trees. Global Change Biology 20(10):3177-3190.

Köhl M, Lasco R, Cifuentes M, Jonsson O, Korhonen KT, Mundhenk P, Navar JD, Stinson G (2015) Changes in forest production, biomass and carbon: result from the 2015 UN FAO global forest resource assessment. Forest Ecol Manag 352:21-34. https://doi.org/10.1016/j.foreco.2015.05.036 
Köppen W (1884) Die Warmezonen Der Erde, Nach Der Dauer Der Heissen, Gemassigten und Kalten Zeit und Nach Der Wirkung Der Warme auf die Organische welt Betrachtet. The thermal zones of the earth according to the duration of hot, moderate and cold periods and to the imp. Meteorol Z 1: 215-226.

Lamprecht, $H$ (1989) Silviculture in the tropics: tropical forest ecosystems and their tree species: possibilities and methods for their long-term utilization. GTZ, Eschborn. 1989. 296 p.

Lindsay Banin, Simon L. Lewis, Gabriela Lopez-Gonzalez, Timothy R. Baker, Carlos A. Quesada, Kuo-Jung Chao, David F. R. P. Burslem, Reuben Nilus, Kamariah Abu Salim, Helen C. Keeling, Sylvester Tan, Stuart J. Davies, Abel Monteagudo Mendoza, Rodolfo Vásquez, Jon Lloyd, David A. Neill, Nigel Pitman, Oliver L. Phillips, Nina Wurzburger, (2014) Tropical forest wood production: a crosscontinental comparison. Journal of Ecology 102(4):1025-1037.

Lobo J, Barrantes G, Castukki M, Quesada R, Maldonado T, Fuchs EJ, Soils S, Quesada M (2007) Effects of selective logging on the abundance, regeneration and short-term survival of Caryocar costaricense (Caryocaceae) and Peltogyne purpurea (Caesalpinaceae), two endemic timber species of southern Central America. Forest Ecol Manag 245(1-3):88-95

Manuri S, Brack C, Nugroho NP, Hergoualc'h K, Novita N, Dotzauer H, Verchot L, Putra CAS, Widyasari E (2014) Tree biomass equations for tropical peat swamp forest ecosystems in Indonesia. Forest Ecol Manag 334:241-253. https://doi.org/10.1016/j.foreco.2014.08.031 Accessed 25 April 2017

Martin PA, Newton AC, Pfeifer M, Khoo M, Bullock JM (2015) Impacts of tropical selective logging on carbon storage and tree species richness: a metaanalysis. Forest Ecol Manag 356:224-233. https://doi.org/10.1016/j.foreco.2 015.07.010 Accessed 25 April 2017

Mazzei L, Sist P, Ruschel A, Putz A, Putz FE, Marco P, Pena W, Ferreira JER (2010) Above-ground biomass dynamics after reduced-impact logging in the eastern Amazon. Forest Ecol Manag 259(3):367-373. https://www.sciencedirect.com/ science/article/pii/S0378112709007737. Accessed 25 April 2017

Medjibe VP, Putz FE, Starkey MP, Ndouna AA, Memiaghe HR (2011) Impacts of selective logging on above-ground forest biomass in the Monts de Cristal in Gabon. Forest Ecol Manag 262(9):1799-1806. https://doi.org/10.1016/j. foreco.2011.07.014 Accessed 25 April 2017

Pan YD, Birdsey RA, Fang JY, Houghton R, Kauppi PE, Kurz WA, Phillips OL, Shvidenko A, Lewis SL, Canadell JG, Ciais P, Jackson RB, Pacala SW, McGuire AD, Piao SL, Rautiainen SS, Hayes D (2011) A large and persistent carbon sink in the world's forests. Science 333(6045):988-993. https://science.sciencemag. org/content/333/6045/988. Accessed 25 April 2017

Pearson TRH, Brown S, Casarim FM (2014) Carbon emissions from tropical forest degradation caused by logging. Environm Res Lett 034017(9):11. https:// iopscience.iop.org/article/10.1088/1748-9326/9/3/034017. Accessed 25 April 2017

Pearson TRH, Brown S, Murray L, Sidman G (2017) Greenhouse gas emissions from tropical forest degradation: an underestimated source. Carbon Balance Manag 12(1):3 http://cbmjournal.springeropen.com/articles/10.1186/s13021017-0072-2. Accessed 25 April 2017

Pélissier R, Pascal JP, Houllier F, Laborde H (1998) Impact of selective logging on the dynamics of a low elevation dense moist evergreen forest in the Western Ghats (South India). Forest Ecol Manag 105(1-3):107-119

Pena-Claros M, Fredericksen TS, Alarcon A, Blate GM, Choque U, Leano C, Licona JC, Mostacedo B, Pariona W, Villegas Z, Putz FE (2008) Beyond reducedimpact logging: silvicultural treatments to increase growth rates of tropical trees. Forest Ecol Manag 256(7):1458-1467. https://www.sciencedirect.com/ science/article/pii/S037811270700881X. Accessed 25 April 2017

Pinard MA, Putz FE (2006) Retaining forest biomass by reducing logging damage. Biotropica 28(3):278-295. https://www.jstor.org/stable/2389193. Accessed 25 April 2017

Poorter L, Bongers F, Aide TM, Almeyda Zambrano AM, Balvanera P, Becknell JM, Boukili V, Brancalion PHS, Broadbent EN, Chazdon RL, Craven D, de AlmeidaCortez JS, Cabral GAL, de Jong BHJ, Denslow JS, Dent DH, DeWalt SJ, Dupuy JM Duran SM, Espirito-Santo MM, Fandino MC, Cesar RG, Hall JS, HernandezStefanoni JL, Jakovac CC, Junqueira AB, Kennard D, Letcher SG, Licona JC, Lohbeck M, Marin-Spiotta E, Martinez-Ramos M, Massoca P, Meave JA, Mesquita R, Mora F, Munoz R, Muscarella R, Nunes YRF, Ochoa-Gaona S, de Oliveira AA, Orihuela-Belmonte E, Pena-Claros M, Perez-Garcia EA, Piotto D, Powers JS, Rodriguez-Velazquez J, Romero-Perez IE, Ruiz J, Saldarriaga JG, Sanchez-Azofeifa A, Schwartz NB, Steininger MK, Swenson NG, Toledo M, Uriarte M, van Breugel $M$, van der Wal H, Veloso MDM, Vester HFM, Vicentini A, Vieira ICG, Bentos TV,
Williamson GB, Rozendaal DMA (2016) Biomass resilience of neotropical secondary forests. Nature 530(7589). https://doi.org/10.1038/nature16512

Priyadi H, Gunarso P, Kanninen M (2005) Permanent sample plots more than just forest data. IInternational Workshop on Promoting Permanent Sample Plots in Asia and the Pacific Region. Bogor, xix, p 169

Raymond CL, Healey S, Peduzzi A, Patterson P (2015) Representative regional models of post-disturbance forest carbon accumulation: integrating inventory data and a growth and yield model. Forest Ecol Manag 336:21-34. https://doi.org/10.1016/j.foreco.2014.09.038 Accessed 25 April 2017

Roopsind A, Wortel V, Hanoeman W, Putz FE (2017) Quantifying uncertainty about forest recovery 32-years after selective logging in Suriname. Forest Ecol Manag 391(February):246-255. https://www.sciencedirect.com/science/ article/pii/S0378112717302256. Accessed 25 April 2017

Ruslandi CWF, Putz FE (2017) Effects of silvicultural intensification on timber yields, carbon dynamics, and tree species composition in a dipterocarp forest in Kalimantan, Indonesia: an individual-tree-based model simulation. Forest Ecol Manag 390:104-118. https://doi.org/10.1016/j.foreco.2017.01.019 Accessed 25 April 2017

Saatchi SS, Harris NL, Brown S, Lefsky M, Mitchard ETA, Salas W, Zutta BR, Buermann W, Lewis SL, Hagen S, Petrova S, White L, Silman M, Morel A (2011) Benchmark map of forest carbon stocks in tropical regions across three continents. PNAS 108(24):9899-9904 http://www.ncbi.nlm.nih.gov/ pubmed/21628575. Accessed 25 April 2017

Sasaki N, Asner GP, Pan Y, Knorr W, Durst PB, Ma HO, Abe I, Lowe AJ, Koh LP, Putz FE (2016) Sustainable management of tropical forests can reduce carbon emissions and stabilize timber production. Front Environm Sci 4(August):50 http://journal.frontiersin.org/article/10.3389/fenvs.2016.00050. Accessed 25 April 2017

Sierra C, Del Valle J, Restrepo HI (2012) Total carbon accumulation in a tropical forest landscape. Carbon Balance Manag 7(1):12. https://www.ncbi.nlm.nih. gov/pmc/articles/PMC3732086/. Accessed 25 April 2017

Sist P, Fimbel R, Sheil D, Nasi R, Chevallier MH (2003a) Towards sustainable management of mixed dipterocarp forests of South-East Asia: moving beyond minimum diameter cutting limits. Environm Conserv 30(4): S0376892903000389. http://www.journals.cambridge.org/abstract_S0376892 903000389. Accessed 25 April 2017

Sist P, Mazzei L, Blanc L, Rutishauser E (2014) Large trees as key elements of carbon storage and dynamics after selective logging in the eastern Amazon. Forest Ecol Manag 318:103-109. https://www.sciencedirect.com/science/ article/pii/S0378112714000073. Accessed 25 April 2017

Sist $P$, Nguyen-Thé N (2002) Logging damage and the subsequent dynamics of a dipterocarp forest in East Kalimantan (1990-1996). Forest Ecol Manag 165(13): 85-103. https://www.sciencedirect.com/science/article/pii/S0378112701 006491. Accessed 25 April 2017

Sist P, Nolan T, Bertault J, Dykstra D (1998) Harvesting intensity versus sustainability in Indonesia. Forest Ecol Manag 108(3):251-260. https://www.sciencedirect.com/ science/article/pii/S037811279800228X. Accessed 6 May 2017

Sist P, Sheil D, Kartawinata K, Priyadi H (2003b) Reduced-impact logging in indonesian borneo: some results confirming the need for new silvicultural prescriptions. Forest Ecol Manag 179(1-3):415-427. https://www.sciencedirect. com/science/article/pii/S0378112702005339. Accessed 25 April 2017

Vidal E, West TAPP, Putz FE (2016) Recovery of biomass and merchantable timber volumes twenty years after conventional and reduced-impact logging in Amazonian Brazil. Forest Ecol Manag 376:1-8. https://www.sciencedirect. com/science/article/pii/S0378112716303000. Accessed 25 April 2017

Villegas Z, Pena-Claros M, Mostacedo B, Alarcon A, Licona JC, Leano C, Pariona W, Choque U (2009) Silvicultural treatments enhance growth rates of future crop trees in a tropical dry forest. Forest Ecol Manag 258(6):971-977

West TAPP, Vidal E, Putz FE (2014) Forest biomass recovery after conventional and reduced-impact logging in Amazonian Brazil. Forest Ecol Manag 314:5963 https://www.sciencedirect.com/science/article/pii/S0378112713007779. Accessed 25 April 2017 